\title{
Uncertainty in the Air. In the Emergency Room with COVID-19 in Pakistan
}

Abuzar Siraj, ${ }^{1}$ Muhammad Waleed Khan. ${ }^{2}$

\section{The Experience}

News of the novel Coronavirus spreading like wildfire in China definitely made it to us, but it always seemed so foreign, so far. It was not until $11^{\text {th }}$ March 2020, when WHO declared it a pandemic, that the gravity of the situation became apparent to us.' Ever since Pakistan confirmed its first 2 cases on $26^{\text {th }}$ February 2020, the numbers keep piling up. As of writing this, the number of confirmed cases stands at a grand total of $3277 .^{2}$

Fresh out of medical school, my classmates and I were looking forward to finally begin our professional career in medicine. I've always wanted to escape from the realm of books and presentations to actually participate in patient care and make a difference in someone's life. When I found out my first rotation was going to be in the medical emergency room (ER), I was both excited and anxious at the same time.

Emergency rooms in Pakistan are one of the busiest in the world. ${ }^{3}$ They also happen to be terribly under-staffed, overcrowded and underresourced. Usually, you are expected to triage patients, decide who needs your urgent help, and administer life saving measures while also catering to the needs of those patients who are not in any immediate threat, all in the span of a few minutes. This balancing act was made exceptionally complicated by the current pandemic.

I arrived on my first day without any personal protective equipment (PPE), barring an old surgical mask from last week. And within a few minutes, my first critically ill patient came into the ER. Pale as a ghost, ice cold to the touch with no palpable pulse, the attending called for immediate CPR (Cardiopulmonary Resuscitation). Our entire team of junior doctors participated with great zeal; chest compressions, blood drawing, intubation. But all in vain, as the patient failed to respond and the code was called off. Thoughts of sadness were quickly turned to that of worry when the attendant explained that the patient had developed a dry cough and fever earlier that day. Ironically, the masks we had could not hide the fear we were wearing on our faces. The tension was palpable in the air. But there was no time to ponder, as the second batch of patients made their way through the ER doors.
I could not help but think about that patient. We did not know for sure if he had COVID19 (Corona Virus Disease 2019) because he was never tested. But what if he did? Does this mean I have it too? Am I passing it on to all the other patients I see or will see? Will I give it to my loved ones at home? If so, I was violating the most critical dictum of the Hippocratic Oath, "first, do no harm."

My shifted ended, and I left for home physically and mentally exhausted. I locked myself in my room, disinfected everything I had with me in the ER. This unseen threat left me with plenty to think about for the night.

On the day of my second shift, the hospital ordered that all outpatient services will be discontinued in an attempt to minimize unnecessary exposure. This meant a greater volume of patients made their way to the ER for conditions that did not need emergent care. Our ER got even more congested which further increased the likelihood of transmission of the virus.

The entire situation was immensely taxing as dozens of suspected cases came through and asked to be treated, which we young doctors had to provide them, without any PPE. It got to a point that the sound of the nebulization machine, which is implicated in spreading aerosols and so increasing transmission ${ }^{4}$, sounded like a grenade going off, spreading contagious debris everywhere.

Experts say the situation will go from bad to worse in the days to come, with the total number of cases projected to reach 50,000 at the end of April 2020. Pakistan is a third world country; our health care system was barely hanging on before this pandemic. Add to that personal risk, outraged relatives, and a culture of mistrust between health care professionals and its civilians, you get a sense of impending doom and gloom, with young doctors at its very center.

\footnotetext{
1 House Officer, Hayatabad Medical Complex, Peshawar, Pakistan.

2 House Officer, Khyber Teaching Hospital, Peshawar, Pakistan.
}

About the Author: Abuzar Siraj is a Junior House Officer in Medical C Ward at Hayatabad Medical Complex, Peshawar, Pakistan. 


\section{Experience}

\section{References}

1. World Health Organization (WHO) Director - General's opening remarks at the media briefing on COVID-19-11 March 2020. Available at: https://www.who.int/dg/speeches/detail/who-director-general-s-openingremarks-at-the-media-briefing-on-covid-19---11-march-2020. Accessed: April 25, 2020. Last update: March 11, 2020.

2. World Health Organization (WHO). Novel Coronavirus (2019-nCoV) situation report 77 - WHO. Geneva. Available at: https://www.who.int/docs/defaultsource/coronaviruse/situation-reports/20200406-sitrep-77-covid19.pdf?sfvrsn=21d1e632_2. Accessed: April 25, 2020. Last update: April 6, 2020.
3. Husseni AM, Ullah MA. The Dire Need of Urgent Care Centers In Pakistan; A Potential Solution To Emergency Room Overcrowding. I Ayub Med Coll Abbottabad. 2019 Jan-Mar;31(1):1-2.

4. Tran K, Cimon K, Severn M, Pessoa-Silva CL, Conly J. Aerosol generating procedures and risk of transmission of acute respiratory infections to healthcare workers: a systematic review. PLoS One. 2012;7(4):e35797.

\section{Acknowledgments}

None

Conflict of Interest Statement a Funding

The Authors have no funding, financial relationships or conflicts of interest to disclose.

Author Contributions

Conceptualization: AS. Validation: AS. Data Curation: MWK. Resources: MWK. Writing - Original Draft: AS. Writing - Review \& Editing: AS, and MWK. Visualization: AS. Supervision: AS. Project Administration: AS, and MWK.

Cite as:

Siraj A, Khan MW. Uncertainty in the Air: In the Emergency Room with CoVID-19 in Pakistan. Int J Med Students. 2020 Jan-Apr;8(1):54-55.

This work is licensed under a Creative Commons Attribution 4.0 International License

ISSN 2076-6327

This journal is published by the University Library System, University of Pittsburgh as part of the Digital Publishing Program and is co-sponsored by the University of Pittsburgh Press. 